\title{
Lettlands Bedeutung \\ für die östliche Frage
}

Von

H. F. Crohn-Wolfgang

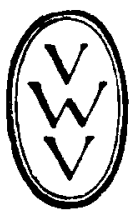

Berlin und Leipzig

Walter de Gruyter \& Co.

vormals G.J. Göschen'sche Verlagshandlung - J. Guttentag, Verlagsbuchhandlung Georg Reimer - Karl J. Trübner - Veit \& Comp. 
Druck von Walter de Gruyter \& Co., Berlin W. 10. 